\title{
ПЕДАГОГІЧНІ УМОВИ ФОРМУВАННЯ ПРОФЕСІЙНОЇ КОМПЕТЕНТНОСТІ МАЙБУТНІХ БАКАЛАВРІВ З ЛАБОРАТОРНОЇ МЕДИЦИНИ
}

zahalnoosvitnoho navchalnoho zakladu [Concept of innovative development of general educational institution]. [Electronic resource]. Available at: http:// w e b c a c h e.google us e r content.com/ search? $\mathrm{q}=$ cache:idgs WEmB0kEJ:undip.org.ua/photo/ koncepciya_i nnovaciynogo_ rozvytku_ ZNZ. $\mathrm{pdf}+\& \mathrm{~cd}=1 \& \mathrm{hl}=\mathrm{uk} \& \mathrm{ct}=\mathrm{clnk} \& \mathrm{gl}=\mathrm{ua}$. [in Ukrainian].

13. Lyniova, I. O. Osvitni innovatsii u systemi pidvyshchennia kvalifikatsii kerivnykiv zahalnoosvitnikh zakladiv [Educational innovations in the system of advanced training of management personnel of general educational institutions]. [Electronic resource]. Available at:http://irbis-nbuv.gov.ua/cgibin/irbis nbuv/ cgiirbis 64.exe?C21COM=2\&I21 DBN= UJRN\& $\underline{\mathrm{P} 21 \mathrm{DBN}=\mathrm{UJRN} \& \text { IMAGE }}$ FILE DOWNLOAD
$=1 \&$ Image file name $=$ PDF/vpm $2010 \quad 7$ 9.pdf [in Ukrainian].

14. Nikolaienko, S. M. (2009). Teoretykometodolohichni osnovy upravlinnia innovatsiinym rozvytkom systemy osvity Ukrainy [Theoretical and methodological bases of management of innovative development of the education system of Ukraine]. Doctor's thesis. Kyiv. 419 p. [in Ukrainian].

15. Kovalchuck, V. \& Vorotnykova, I. (2017). Ecoaching, E-mentoring for lifelong professional development of teachers within the system of postgraduate pedagogical education. Turkish Online Journal of Distance Education-TOJDE. pp. 214-227. [in English].

Стаття надійшла до редакції 02.03.2018

УДК 378.046:61

DOI:

Орися Любінська, асистент кафедри лабораторної медицини ВНКЗ ЛОР “Львівського інституту медсестринства та лабораторної медицини імені Андрея Крупинського”,

\section{ПЕДАГОГІЧНІ УМОВИ ФОРМУВАННЯ ПРОФЕСІЙНОЇ КОМПЕТЕНТНОСТІ МАЙБУТНІХ БАКАЛАВРІВ З ЛАБОРАТОРНОЇ МЕДИЦИНИ}

У статті обтрунтовано педагогічні умови формування професійної компетентності майбутніх бакалаврів з лабораторної медицини. Педагогічні умови визначено як спеціально створені обставини, чинники дії та взаємодії суб'єктів педагогічного процесу, щзо реалізуються в межах иьього проиесу, сукупність яких визначає результативність формування професійної компетентності майбутніх бакалаврів з лабораторної медицини у вищих навчальних закладах.

Ключові слова: педагогічні умови; формування професійної компетентності; майбутні бакалаври з лабораторної медицини.

Jim. 11.

\begin{abstract}
Orysy a Lyubinska, Assistant of the Laboratory Medicine Department State Educational Communal Establishment Lviv Region Council "Lviv Andriy Krupynskiy Institute of Nursing and Laboratory Medicine"
\end{abstract}

\section{PEDAGOGICAL CONDITIONS OF THE FORMATION OF PROFESSIONAL} COMPETENCE OF FUTURE BACHELORS OF LABORATORY MEDICINE

The article deals with the pedagogical conditions of formation of professional competence of bachelors of laboratory medicine. The pedagogical conditions are defined as the specially created circumstances, the factors of action and interaction between the subjects of pedagogical process, realized within this process, the totality of which determines the effectiveness of the formation of professional competence of future bachelors of laboratory medicine in the higher educational institutions.

Emphasizing the pedagogical conditions, we took into account that only the holistic and integrated implementation of them into the educational process of higher educational establishment can affect the formation of the professional competence of future bachelors of laboratory medicine.

Taking into account the didactic principles, the different approaches of scientists to the pedagogical conditions and practice of professional training of future bachelors of laboratory medicine in higher educational establishments made it possible to determine the following pedagogical conditions of the formation of professional competence of medical students, namely:

- formation of the motivational-value relation to the profession of a specialist in laboratory medicine;

- gradual formation and development of professional competence of future bachelors of laboratory medicine;

- application of innovative technologies of the theoretical and practical training of future bachelors of laboratory medicine.

The determined pedagogical conditions in the various forms, methods, and technologies of studying, 


\section{ПЕДАГОГІЧНІ УМОВИ ФОРМУВАННЯ ПРОФЕСІЙНОӤ КОМПЕТЕНТНОСТІ МАЙБУТНІХ БАКАЛАВРІВ З ЛАБОРАТОРНОЇ МЕДИЦИНИ}

will increase the efficiency of forming the professional competence of future bachelors of laboratory medicine in higher educational institutions and will enable them to quickly involve into the professional activities. medicine.

Keywords: pedagogical conditions; formation of professional competence; a future bachelor of laboratory

$\Pi$ остановка проблеми у загальному вигляді. Для досягнення рівня світових стандартів у нашій країні відбуваються реформи, які несуть зміни і в освітній галузі, що можуть забезпечити якісну професійну підготовку майбутніх фахівців. В Україні діє програма реформування медичної освіти, яка стосується і бакалаврів з лабораторної медицини та спрямована на вдосконалення системи підготовки таких фахівців.

Для ефективного формування у студентівмедиків у вищих навчальних закладах досліджуваної компетентності необхідно визначити, теоретично обгрунтувати педагогічні умови формування професійної компетентності майбутніх бакалаврів 3 лабораторної медицини.

Аналіз останніх досліджень і публікацій. Аналіз психолого-педагогічної літератури надав можливість встановити, що проблема професійної підготовки майбутніх фахівців досить грунтовно досліджена на рівні загальних положень педагогіки та психології А. Алексюк, В. Боднар, С. Гончаренко, Р. Гуревич, Н. Кузьміна, А. Маркова, В. Сєріков, В. Сластьонін та ін. Упровадження компетентнісного підходу до професійної підготовки фахівців В. Луговий, В. Радкевич, В. Ягупов та ін. Формування професійної компетентності чи їі складових майбутніх медичних фахівців присвячено наукові пошуки О. Борисюк, І. Бойчук, Р. Дем'янчук, Я. Кульбашної, І. Радзієвської, М. Мруги, 3. Шарлович та інші.

Аналіз та узагальнення результатів наукових досліджень, показує, що професійна компетентність майбутніх фахівців починає формуватися в освітньому середовищі та розвивається під час професійної діяльності. Низка науковців вважає, що для формування професійної компетентності майбутніх фахівців, доцільно обгрунтувати педагогічні умови які б допомогли вирішенню певних педагогічних завдань.

Проте, незважаючи на вагомі наукові результати досліджень, поза увагою дослідників залишилася проблема обгрунтування педагогічних умов формування професійної компетентності майбутніх бакалаврів $з$ лабораторної медицини у вищих навальних закладах.

Метою статті $\epsilon$ обгрунтування педагогічних умов формування професійної компетентності майбутніх бакалаврів з лабораторної медицини у вищих навчальних закладах.

Виклад основного матеріалу дослідження. Науковий аналіз проблеми формування професійної компетентності майбутніх бакалаврів 3 лабораторної медицини передбачає низку педагогічних умов, що надають змогу ефективно побудувати процес формування зазначеної компетентності.

Поняття “педагогічні умови” тлумачиться по різному. Так, зокрема:

- комплекс спеціально спроектованих генеральних чинників впливу на зовнішні та внутрішні обставини навчально-виховного процесу й особистісні параметри всіх його учасників; які забезпечують цілісність навчання та виховання в інформаційно-освітньому середовищі навчального закладу відповідно до вимог суспільства та запитів ринку праці, сприяють всебічному гармонійному розвиткові особистості та створюють сприятливі можливості для виявлення іiї задатків, врахування потреб і формування загальнолюдських і професійно важливих якостей, ключових кваліфікацій, загальних і професійних компетенцій $[8,28]$.

- у підручнику з педагогіки вищої медичної освіти за ред. С. Максименко педагогічні умови розглядаються як “значущий компонент педагогічного процесу, який інтегрує певну сукупність педагогічних заходів, спрямованих на досягнення поставленої мети" $[10,173]$.

Отже, опираючись на наведені дефініції, педагогічні умови визначено як спеціально створені обставини, чинники дії та взаємодії суб' єктів педагогічного процесу, що реалізуються в межах цього процесу, сукупність яких визначає результативність формування професійної компетентності майбутніх бакалаврів 3 лабораторної медицини у ВНЗ

Виокремлюючи педагогічні умови, ми враховували що лише цілісна та комплексна реалізація їх в освітньому процесі ВНЗ, може впливати на ефективність формування професійної компетентності майбутніх бакалаврів 3 лабораторної медицини.

У контексті нашого дослідження нами проаналізовано різні підходи науковців до виокремлення ними педагогічних умов щодо формування професійної компетентності або ж її складових у майбутніх фахівців медичної галузі. 


\section{ПЕДАГОГІЧНІ УМОВИ ФОРМУВАННЯ ПРОФЕСІЙНОЇ КОМПЕТЕНТНОСТІ МАЙБУТНІХ БАКАЛАВРІВ З ЛАБОРАТОРНОЇ МЕДИЦИНИ}

Так, дослідниця А. Варданян [3, 13] визначає такі педагогічні умови формування професійномовленнєвої компетентності майбутніх лікарів: проектування змісту мовної освіти на основі інтеграції та індивідуальної мотивації навчання майбутніх лікарів; використання комплексу інтерактивних технологій навчання, спрямованих на освітню активність студентів; удосконалення навчально-методичного забезпечення 3 формування професійно-мовленнєвої компетентності майбутніх лікарів засобом упровадження авторського спецкурсу.

Досліджуючи особливості формування паліативної компетентності бакалаврів медицини в процесі професійної підготовки, Л. Білик визначає наступні педагогічні умови: формування мотиваційної сфери бакалаврів медицини, спрямованої на інтеріоризацію професійних цінностей; організація особистісно орієнтованої підготовки студентів на основі гуманізації взаємодії суб'єктів педагогічного процесу та розвитку їх моральних якостей; конструювання змісту навчального матеріалу з паліативної допомоги у вигляді ситуаційних завдань, адекватних спроектованим компетенціям; прищеплення деонтологічних навичок на доклінічному етапі навчання, використання сучасних інноваційних технологій розвитку комунікативних умінь бакалаврів медицини; активізація волонтерської діяльності, наставництва та соціальної позиції молоді в процесі підготовки бакалаврів медицини $[1,5-6]$.

Л. Борисюк, досліджуючи формування професійної компетентності майбутніх бакалаврів сестринської справи в процесі вивчення хімікобіологічних дисциплін, визначає та теоретично обгрунтовує наступні педагогічні умови: актуалізація ціннісного потенціалу хімікобіологічних дисциплін у професійній підготовці майбутніх бакалаврів сестринської справи; трансформація змісту навчального матеріалу та його конструювання увигляді міждисциплінарних професійно зорієнтованих хіміко-біологічних завдань; сприяння опануванню студентами вмінь, навичок й досвіду вирішення інтегрованих хімікобіологічних завдань професійного спрямування; організація комплексної самоосвітньої роботи студентів із вивчення хіміко-біологічних дисциплін $[2,14]$.

Натомість, М. Демянчук, педагогічними умовами реалізації компетентнісного підходу в підготовці майбутніх бакалаврів сестринської справи визначив: створення мотиваційноціннісного середовища в навчальному процесі задля вироблення у студентів ціннісного ставлення до опанування фахом бакалавра медсестринської справи, спрямування майбутніх бакалаврів медсестринства на розширення когнітивної складової професійного світогляду на основі вивчення дисциплін “Історія медицини та медсестринства” і “Медсестринська етика та деонтологія", організація самоосвітньої діяльності і вироблення у студентів умінь і навичок етичнодеонтологічної поведінки як ціннісного надбання особистості майбутнього бакалавра медсестринської справи $[5,110]$.

Широкий спектр педагогічних умов обгрунтовує I. Радзієвська, які, на думку дослідниці, забезпечують формування професійної компетентності майбутніх медичних сестер у процесі вивчення фахових дисциплін, а це: організація особистісно орієнтованої підготовки майбутніх медичних сестер; використання компетентнісно-діяльнісного підходу з виконанням ділових ігор та ситуаційних задач 3 елементами доказової медицини; застосування кредитно-модульної технології навчання у процесі вивчення фахових дисциплін; активізація самостійної професійної діяльності студентів під час здійснення медсестринського процесу на реальних базах практики $[11,6]$.

Виокремлюючи педагогічні умови формування професійної компетентності майбутніх бакалаврів з лабораторної медицини провідними аспектами ми визначали наступні:

- врахування соціального замовлення суспільства щодо забезпечення якісного надання медичних послуг, зокрема лабораторної медицини;

- особливості професійної діяльності бакалаврів з лабораторної медицини в умовах закладів охорони здоров'я;

- реалізація компетентнісного підходу до підготовки сучасного медичного фахівця;

- усвідомлення студентами-медиками необхідності формування професійної компетентності та мотивації щодо їі вдосконалення;

- врахування особистої рефлексії студентів як суб'єктів професійної діяльності у галузі лабораторної медицини.

Ураховуючи дидактичні принципи, різні підходи науковців до педагогічних умов та практики професійної підготовки майбутніх бакалаврів з лабораторної медицини у ВНЗ дало можливість визначити наступні педагогічні умови формування професійної компетентності студентів-медиків, а саме:

- формування мотиваційно-ціннісного ставлення до оволодіння професією фахівця 3 лабораторної медицини; 


\section{ПЕДАГОГІЧНІ УМОВИ ФОРМУВАННЯ ПРОФЕСІЙНОЇ КОМПЕТЕНТНОСТІ МАЙБУТНІХ БАКАЛАВРІВ З ЛАБОРАТОРНОЇ МЕДИЦИНИ}

- поетапне формування та розвиток професійної компетентності майбутніх бакалаврів 3 лабораторної медицини;

- застосування інноваційних технологій теоретичної та практичної професійної підготовки майбутніх бакалаврів $з$ лабораторної медицини.

Перша педагогічна умова стосується мотиваційної сфери, а саме - передбачає формування у студентів мотиваційно-ціннісного ставлення до оволодіння професією фахівия 3 лабораторноїмедицини.

I. Ляшенко наголошує, що професійна мотивація відіграє роль компенсаторного фактора: в умовах недостатньо розвинутих здібностей студента за наявності професійної мотивації може досягти більших успіхів, ніж здібний студент, у якого не сформована професійна мотивація. Тому цілеспрямоване формування професійної мотиваціїє одним із першочергових завдань вищої школи [9].

Професійна мотивація - це сукупність чинників і процесів, які відбиваючись у свідомості, спонукають особистість до вивчення та ефективної реалізації професійної діяльності $[6,21]$.

3 метою формування у студентів мотиваційноціннісного ставлення до оволодіння професією фахівця 3 лабораторної медицини необхідно викладачам особливу увагу приділяти стимулюванню їх до активної участі в освітньому процесі. Також вважаємо, що професійні ціннісні орієнтації не виникають раптово, а формуються поступово, упродовж навчання у ВНЗ і у процесі безпосередньої діяльності.

3 метою забезпечення мотиваційно-ціннісної сфери майбутніх бакалаврів 3 лабораторної медицини важливим є:

- ознайомлення студентів-медиків із суспільною значущістю їхнього обраного фаху;

- ознайомлення майбутніх бакалаврів 3 лабораторної медицини 3 їх професійною діяльністю та вимогами до знань, умінь і якостей особистості фахівця;

- створення уявлень про професіонала 3 обраної спеціальності;

- усвідомлення перспективних і безпосередніх цілей професійного навчання;

- формування ціннісних орієнтацій, пов'язаних із професійною діяльністю.

Для розвитку професійної мотивації студентів необхідно їх залучати до написання есе, організовувати 3 ними бесіди на теми, що пов'язані з різними аспектами їхньої майбутньої професійної діяльності, допомагати опановувати методики рефлексивного аналізу власних досягнень; організовувати зустрічі 3 висококваліфікованими фахівцями в галузі лабораторної медицини; залучати студентів до різних видів науково-дослідницької та навчальнодослідницької роботи, участі в науковопрактичних конференціях на професійну тематику; організовувати майстер-класи для наочного ознайомлення з високопрофесійними виконаннями різних видів професійної діяльності.

Друга умова - це поетапне формування та розвиток у студентів професійної компетентності.

Формування професійної компетентності майбутніх бакалаврів 3 лабораторної медицини має здійснюватися поетапно, кожен з яких має свої завдання, які поступово ускладнюються на заняттях у ВНЗ, так і у процесі різних видів практик. Спочатку використовуються способи взаємодії, що забезпечують введення особистості у навчальну професійну діяльність. Пізніше використовуються репродуктивні та підтримані викладачами дії студентів. На наступному етапі - самоспонукальні, самоорганізовані дії студентів.

Оскільки професійна компетентність майбутнього бакалавра з лабораторної медицини складне інтегративне утворення, тому при іï формуванні необхідно враховувати компоненти досліджуваної компетентності: мотиваційноціннісннісний, знаннєвий, організаційнотехнологічний та рефлексивний.

Для забезпечення поетапного формування компонентів професійної компетентності майбутніх бакалаврів 3 лабораторної медицини слід організовувати професійну підготовку у ВНЗ так, щоб забезпечити використання різних форм організації освітнього процесу 3 метою зацікавлення студентів майбутньою професійною діяльністю, стимулювання мотивації щодо вдосконалення професійних цінностей та якостей.

Третя умова - застосування інноваційних технологій теоретичної та практичної професійної підготовки майбутніх бакалаврів 3 лабораторної медицини.

Ми уважаємо, що максимальне наближення технологій професійної підготовки майбутніх бакалаврів $з$ лабораторної медицини у ВНЗ до медичної практики, допоможе їм адаптуватися до професійної діяльності.

Я. Кульбашна зазначає [7, 292], що у освітньому процесі використовується лише обмежена кількість інноваційних педагогічних технологій. Тому дуже важливо для формування професійної компетентності майбутніх бакалаврів 3 лабораторної медицини розробляти й упроваджувати інноваційні педагогічні технології.

Упровадження у процес професійної підготовки 3 метою формування професійної 


\section{ПЕДАГОГІЧНІ УМОВИ ФОРМУВАННЯ ПРОФЕСІЙНОЇ КОМПЕТЕНТНОСТІ МАЙБУТНІХ БАКАЛАВРІВ ЗЛАБОРАТОРНОЇ МЕДИЦИНИ}

компетентності майбутніх бакалаврів 3 лабораторної медицини інноваційних педагогічних технологій має відбуватися системно та комплексно. Таке навчання, завдяки застосуванню інноваційних технологій спрямоване на розвиток особистості майбутнього бакалавра з лабораторної медицини, оскільки студенти залучаються до самостійного вирішення складних проблем, прийнятті рішень які можуть виникнути в реальній професійній діяльності майбутніх бакалаврів $з$ лабораторної медицини як в типових та нетипових ситуаціях.

Важливим на нашу думку $є$ використання інтерактивних технологій навчання, які надають можливість студентам обмінюватись думками, ідеями пропозиціями, освітній процес організовується таким чином, що багато студентів залучені до процесу пізнання.

Ефективну трансформацію навчальної діяльності студентів-медиків у професійну забезпечує технологія контекстного навчання. Контекстним є таке навчання, за допомого форм, методів і засобів навчання поступово моделюється предметний та соціальний зміст майбутньої професійної діяльності студентів [4, 52].

Для формування професійної компетентності майбутніх бакалаврів 3 лабораторної медицини у ВНЗ пропонуємо застосовувати ігрові технології, які активізують професійне мислення і поведінку студентів, підвищують їхню зацікавленість, спонукають висловлювати свої погляди щодо вироблення пропозицій і прийняття певних рішень.

Технології проблемного навчання також відіграють важливу роль у процесі формування професійної компетентності майбутніх бакалаврів 3 лабораторної медицини, націлені на стимулювання інтересу студентів до нових знань, створюються ситуації, а студенти на основі одержаних знань мають самостійно визначати способи їх вирішення.

Важливим є застосування інформаційнокомунікаційних технологій у процесі формування професійної компетентності майбутніх бакалаврів 3 лабораторної медицини під час теоретичної та практичної професійної підготовки. Їх упровадження у ВНЗ дозволить не тільки прискорити та якісно покращити набуття знань, умінь і професійних навичок, а й дозволить озброїти їх навичками застосування інформаційно-комунікаційних технологій у майбутній професійній діяльності.

Висновок. Визначені педагогічні умов у різних формах, методах, технологіях навчання підвищить ефективність формування професійної компетентності майбутніх бакалаврів 3 лабораторної медицини у ВНЗ та дасть їм змогу швидко включитися у професійну діяльність.

Перспективи подальших розвідок у даному напрямку вбачається в обгрунтуванні та апробації кожної педагогічної умови.

\section{ЛІТЕРАТУРА}

1. Білик Л. В. Формування паліативної компетентності бакалаврів медицини в процесі професійної підготовки: автореф. дис. на здобуття наук. ступеня канд. пед. наук: спец. 13.00.04 “Теорія та методика професійної освіти" / Л. В. Білик. - Пер.Хмельн. 2015. - 20 с.

2. Борисюк Л. О. Формування професійної компетентності майбугніх бакалаврів сестринської справи у процесі вивчення хіміко-біологічних дисциплін: автореф. дис. на здобуття наук. ступеня канд. пед. наук: спец. 13.00.04 “Теорія та методика професійної освіти"/ Борисюк Леся Олександрівна; - Х., 2016. - 20 с.

3. Варданян А. О. Формування професійномовленнєвої компетентності майбутніх лікарів: автореф. дис. на здобуття наук. ступеня канд. пед. наук: спец. 13.00.04 “Теорія та методика професійної освіти” / А. О. Варданян. - Х., 2017. $-20 \mathrm{c}$.

4. Вербицкий А. А. Компетентностный подход и теория контекстного обучения: мат. к четвертому засед. методол. семинара / А. А. Вербицкий. - М.: ИЦ ПКПС, 2004. - 84 с.

5. Демянчук М. Р. Педагогічні умови підготовки майбутніх бакалаврів медсестринської справи на засадах компетентнісного підходу / М. Р. Демянчук // Науковий вісник Миколаївського національного університету імені В. О. Сухомлинського. Педагогічні науки. -2015. - № 1 (48). - C. 108-112.

6. Єрохін С. А. Концепція професійної мотивації студентів як фактору конкурентності на ринкупраці / С. А. Єрохін, Ю. В. Нікітін, І. В. Нікітіна // Юридична наука. 2011. - №1. - С. 20-28.

7. Кульбашна Я. А.Формування професійної компетентності майбутніх фахівців із стоматологогії: теоретичні й методичні основи: монографія / Я. А. Кульбашна. - К. : Компас, 2014. $-416 \mathrm{c}$.

8. Литвин А. В. Методологічні засади поняття “педагогічні умови”: на допомогу здобувачам наукового ступеня / А. В. Литвин. - Львів: СПОЛОМ, 2014. - 76 c.

9. Ляшенко I.В. Формування професійної мотивації студентів до успішної фахової діяльності [Електронний ресурс] / I. В. Ляшенко // Народна освіта - 2013. - Вип. 1 (19). - Режим доступу до 


\section{ПЕДАГОГІЧНІ УМОВИ ФОРМУВАННЯ ПРОФЕСІЙНОЇ КОМПЕТЕНТНОСТІ МАЙБУТНІХ БАКАЛАВРІВ З ЛАБОРАТОРНОЇ МЕДИЦИНИ}

журн.: http://www.narodnaosvita.kiev.ua/?page id $=1076$.

10. Максименко С. Д. Педагогіка вищої медичної освіти: підручник / С. Д. Максименко, М. М. Філоненко - К.: Центр учбової літератури, 2014. - 288 c.

11. Радзієвська I. В. Формування професійної компетентності майбутніх медичних сестер у процесі вивчення фахових дисциплін : автореф. дис. на здобуття наук. ступеня канд. пед. наук: спец.13.00.04. “Теорія та методика професійної освіти” / І. В. Радзієвська. - К., 2011. - 20 с.

\section{REFERENCES}

1. Bilyk, L. V. (2015). Formuvannia paliatyvnoi kompetentnosti bakalavriv medytsyny $\mathrm{v}$ protsesi profesiinoi pidhotovky [Formation of palliative competence of bachelor of medicine in the process of professional training]. Extended abstract of candidate's thesis. Pereiaslav Khmelnytskyi, $20 \mathrm{p}$. [in Ukrainian].

2. Borysiuk, L. O. (2016). Formuvannia profesiinoi kompetentnosti maibutnikh bakalavriv sestrynskoi spravy u protsesi vyvchennia khimiko-biolohichnykh dystsyplin [Formation of professional competence of future bachelors of nursing in the process of study of the chemical and biological disciplines]. Extended abstract of candidate's thesis. Khmelnytskyi,20 p. [in Ukrainian].

3. Vardanian, A. O. (2017.) Formuvannia profesiinomovlennievoi kompetentnosti maibutnikh likariv [Formation of vocational and speech competence of future doctors]. Extended abstract of candidate's thesis. Khmelnytskyi, 20 p. [in Ukrainian].

4. Verbitskiy, A. A. (2004). Kompetentnostnyy podkhod i teoriya kontekstnogo obucheniya [The competence approach and theory of contextual teaching: the materials of the fourth session of the methodological seminar]. Moscov, 84 p. [in Russian].

5. Demianchuk, M. R. (2015). Pedahohichni umovy pidhotovky maibutnikh bakalavriv medsestrynskoi spravy na zasadakh kompetentnisnoho pidkhodu [Pedagogical conditions of preparation of future bachelors of nursing on the basis of competence approach]. Scientific herald of Mykolayiv Vasyl Sukhomlynskiy National University. Pedagogical sciences. No. 1 (48), pp. 108-112. [in Ukrainian].

6. Ierokhin, S. A., Nikitin, Yu. V. \& Nikitina, I. V. (2011). Kontseptsiia profesiinoi motyvatsii studentiv yak faktoru konkurentnosti na rynku pratsi [The concept of professional motivation of students as a factor of competitiveness in the labor market]. Legal science. No.1, pp. 20-28. [in Ukrainian].

7. Kulbashna, Ya. A. (2014). Formuvannia profesiinoi kompetentnosti maibutnikh fakhivtsiv iz stomatolohohii: teoretychni y metodychni osnovy [Formation of professional competence of future specialists in dentistry: the theoretical and methodological foundations]. Kyiv, Kompas, 416 p. [in Ukrainian].

8. Lytvyn, A. V. (2014). Metodolohichni zasady poniattia "pedahohichni umovy" [The methodological foundations of the concept "pedagogical conditions": for the help for applicants of scientific degree]. Lviv: SPOLOM, 76 p. [in Ukrainian].

9. Liashenko, I.V. (2013). Formuvannia profesiinoi motyvatsii studentiv do uspishnoi fakhovoi diialnosti [Formation of professional motivation of students for successful professional activity]. [Electronic recource]. Folk education, vol. 1 (19). Available at: http:// www.narodnaosvita.kiev.ua/?page_id $=1076$. [in Ukrainian].

10. Maksymenko, S. D. \& Filonenko, M. M. (2014). Pedahohika vyshchoi medychnoi osvity [Pedagogy of higher medical education]. Kyiv: Tsentr uchbovoi literatury, 288 p. [in Ukrainian].

11. Radziievska, I. V. (2011). Formuvannia profesiinoi kompetentnosti maibutnikh medychnykh sester u protsesi vyvchennia fakhovykh dystsyplin [Formation of professional competence of future nurses in the process of studying the specialized disciplines]. Extended abstract of candidate's thesis. Kyiv, 20 p. [in Ukrainian].

Стаття надійшла до редакції 15.03.2018

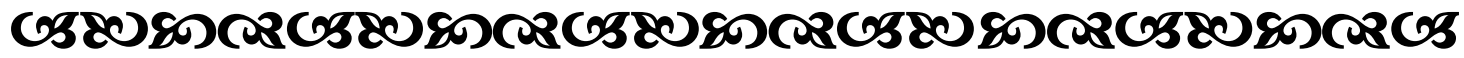

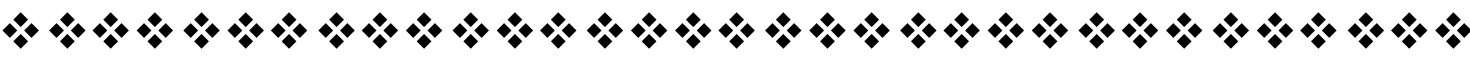 "Дамати стереотипи й пробиватися крізь упередження - справа неймовірно складна, але ще й бантастично приємна".}

